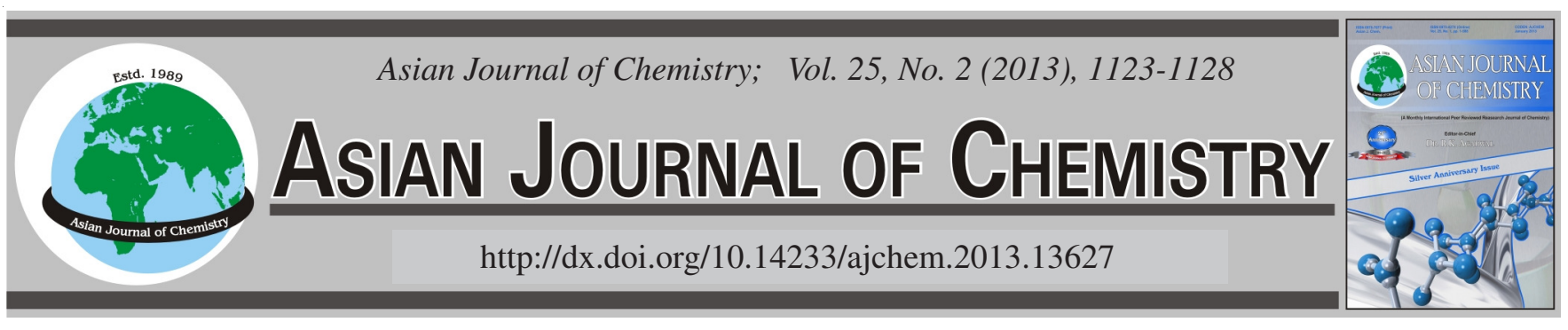

\title{
Determination of Preservative Parabens in Oral and Injection Formulations by HPLC
}

\author{
SAAD AnTAKLI*, Raghad Kabani and Duha ShaWA
}

Department of Chemistry Faculty of Science University of Aleppo, Aleppo, Syria

*Corresponding author: E-mail: antakli@scs-net.org

(Received: 20 February 2012;

\begin{abstract}
Two new HPLC-UV methods are described for determining methyl paraben and propyl paraben, methyl paraben sodium and propyl paraben sodium in oral and injection formulations. Separation of methyl paraben and propyl paraben, methyl paraben sodium and propyl paraben sodium by first method was effected by using an isocratic mobile phase of acetate buffer $(\mathrm{pH}=4): \mathrm{methanol}(18: 82)$ on a $5 \mu \mathrm{m}$ SGE C18 HQ 105 column $(25 \mathrm{~cm} \times 4.6 \mathrm{~mm})$, the detector wavelength was set at $254 \mathrm{~nm}$. Whereas the separation of methyl paraben and propyl paraben, methyl paraben sodium and propyl paraben sodium by second method was achieved by using mobile phase of acetate buffer $(\mathrm{pH}=4)$ :acetonitrile $(20: 80)$ on a $5 \mu \mathrm{m}$ SGE C18 HQ 105 column $(25 \mathrm{~cm} \times 4.6 \mathrm{~mm})$, with UV detection at $254 \mathrm{~nm}$. In both methods conditions, pump flow rate was $1 \mathrm{~mL} / \mathrm{min}$ and sample injection volume $20 \mu \mathrm{L}$. Under these two methods conditions, separation of each two components was achieved in less than 6 min with a good resolution. Finally, these two HPLC methods are simple and quick for routine quantitative analysis of preservative parabens.
\end{abstract}

Key Words: Preservative, HPLC, Methylparaben, Propylparaben, Methylparaben sodium, Propylparaben sodium.

\section{INTRODUCTION}

Among many additives and preservatives have been widely used in food, drugs and cosmetic products to prevent their aging and decay ${ }^{1}$. They can be found in foods, beverages, pharmaceuticals and personal care products ${ }^{2}$. However, these preservatives may be harmful to consumers due to their tendency to induce allergic contact dermatitis. Parabens, esters of $p$-hydroxybenzoic acid (including methyl, ethyl, propyl, butyl, etc.) and their salts (Fig. 1) have been widely used as antimicrobial and antifungal agents in food, beverages, cosmetics and pharmaceuticals ${ }^{3}$, due to their broad antimicrobial spectrum with good stability and non-volatility ${ }^{4}$. Therefore, the determination of these preservatives parabens in pharmaceutical products is important for both quality assurance and consumer safety. Many analytical procedures have been reported for the determination of methyl paraben and propyl paraben preservatives separately or in combination with other drugs by HPLC ${ }^{5,6}$ and other techniques, such as UHPLC-tandem mass spectrometry ${ }^{7}$, fluid extraction combined with liquid chromatography-mass spectrometry ${ }^{8}$, spectrophotometric analysis ${ }^{9}$, electrochemical analysis ${ }^{10}$, flow injection analysis coupled to a monolithic column ${ }^{11}$, fluid extraction combined with gas chromatography-mass spectrometry ${ }^{12}$, NIR spectroscopy ${ }^{13}$ and micellar electrokinetic chromatography. But there are no reports on the simultaneous determination of methyl paraben sodium and propyl paraben sodium.
The aim of the present study was to develop a speedily and sensitive HPLC conditions for the simultaneous determination of methyl paraben and propyl paraben or methyl paraben sodium and propyl paraben sodium.<smiles>COC(=O)c1ccc(O)cc1</smiles>

(a)

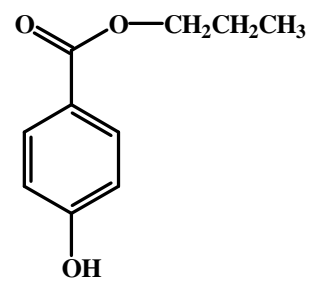

(b)<smiles>COC(=O)c1ccc([N+](=O)[O-])cc1</smiles>

(c)<smiles></smiles>

(d)
Fig. 1. Structure of the analytes: (a) methyl paraben, (b) propyl paraben, (c) methyl paraben sodium, (d) propyl paraben sodium

\section{EXPERIMENTAL}

The solvents and materials were used as analytical grade: water, ethanol (Merck), acetonitrile, methanol (Isolab) were HPLC grade and sodium acetate (Merck), glacial acetic acid 
(Isolab), methyl paraben (purity $99.6 \%$ ) and propyl paraben (purity $99.22 \%$ ) (Clariant, UK), methyl paraben sodium (purity $99.85 \%$ ) and propyl paraben sodium (purity $99.7 \%$ ) (Salicylates and Chemicals, India).

HPLC analysis was performed on an YL 9100 HPLC System equipped with binary pump YL9111, vacuum degasser series YL9101, YL9130 column compartment and YL9120 UV/VIS detector. Chromatographic separations were obtained by using $5 \mu \mathrm{m}$ SGE C18 HQ 105 column $(25 \mathrm{~cm} \times 4.6 \mathrm{~mm})$. Ultrasonic bath (Daihan), analytical balance TE64 Sartorious sensitivity $0.01 \mathrm{mg}$, Germany digital pipettes (Isolab).

\section{Standards stock solutions}

Methyl paraben and propyl paraben solution: $1 \mathrm{mg} / \mathrm{mL}$ and $0.2 \mathrm{mg} / \mathrm{mL}$ of methyl paraben and propyl paraben was prepared respectively by dissolving $100.6 \mathrm{mg}$ of methyl paraben and $20.2 \mathrm{mg}$ of propyl paraben with $20 \mathrm{~mL}$ ethanol in $100 \mathrm{~mL}$ volumetric flask and diluted up to the volume with HPLC-grade water.

Methyl paraben sodium and propyl paraben sodium solution: $1 \mathrm{mg} / \mathrm{mL}$ and $0.2 \mathrm{mg} / \mathrm{mL}$ of methyl paraben sodium and propyl paraben sodium was prepared respectively by weighing $20.2 \mathrm{mg}$ of propyl paraben sodium and $102.5 \mathrm{mg}$ of methyl paraben sodium, in $100 \mathrm{~mL}$ volumetric flask and diluted to the volume by HPLC-grade water.

\section{Sample preparation}

Syrup: A $4 \mathrm{~mL}$ of syrup was transferred to a $100 \mathrm{~mL}$ volumetric flask, the volume was completed to $100 \mathrm{~mL}$ using HPLC-grade water and filtered through a $0.45 \mu \mathrm{m}$ nylon syringe filter and degassed by ultrasonication and then the samples were injected in the chromatograph.

Ampoules: Containing five ampoules was transferred to a beaker then a $4 \mathrm{~mL}$ of it was transferred to a $100 \mathrm{~mL}$ volumetric flask, the volume was completed to $100 \mathrm{~mL}$ using HPLC-grade water, then filtered through a $0.45 \mu \mathrm{m}$ nylon syringe filter and degassed by ultrasonication and then the samples were injected in the chromatograph.

Mobile phase: The mobile phase consisted of $18 \%$ sodium acetate buffer and $82 \%$ HPLC-grade methanol for the first method, $20 \%$ sodium acetate buffer and $80 \%$ HPLCgrade acetonitrile for the second method, (sodium acetate buffer was prepared by weighing $2.72 \mathrm{~g}$ sodium acetate and dissolving it in 1 L HPLC-grade water). Mobile phase $\mathrm{pH}$ was adjusted to 4 by glacial acetic acid. All mobile phase were filtered through a $0.45 \mu \mathrm{m}$ membrane filter and degassed by ultrasonication.

Chromatographic conditions: Table-1 presents the first and the second chromatographic methods conditions, which were applied for simultaneous determination of methyl paraben and propyl paraben or methyl paraben sodium and propyl paraben sodium.

\section{RESULTS AND DISCUSSION}

Chromatograms of the standards solutions of mixture (methyl paraben and propyl paraben) at five different standard concentrations, which every concentration was injected five times under optimized in two methods conditions showed that methyl paraben was well separated from propyl paraben with
TABLE-1

FIRST AND SECOND CHROMATOGRAPHIC METHODS

\begin{tabular}{lll}
\hline \multicolumn{1}{c}{ Specification } & \multicolumn{1}{c}{ First HPLC method } & Second HPLC method \\
\hline Column & SGE C18 HQ 105 & SGE C18 HQ 105 \\
Mobile phase & Acetate buffer $(\mathrm{pH} 4):$ & Acetate buffer $(\mathrm{pH} 4):$ \\
& methanol (18:82) & acetonitrile $(20: 80)$ \\
Flow rate & $1 \mathrm{~mL} / \mathrm{min}$ & $1 \mathrm{~mL} / \mathrm{min}$ \\
Temperature & $30^{\circ} \mathrm{C}$ & $30^{\circ} \mathrm{C}$ \\
Detector & $\mathrm{UV} 254 \mathrm{~nm}$ & $\mathrm{UV} 254 \mathrm{~nm}$ \\
Injection volume & $20 \mu \mathrm{L}$ & $20 \mu \mathrm{L}$ \\
\hline
\end{tabular}

good resolution (Fig. 2). Also chromatograms of the standards solutions of mixture (methyl paraben sodium and propyl paraben sodium) at five different standard concentrations which every one of it was injected five times under suggested chromatographic conditions in both methods gave good separation and resolution (Fig. 3). The separation of each two components in two methods was achieved in less than 6 min.
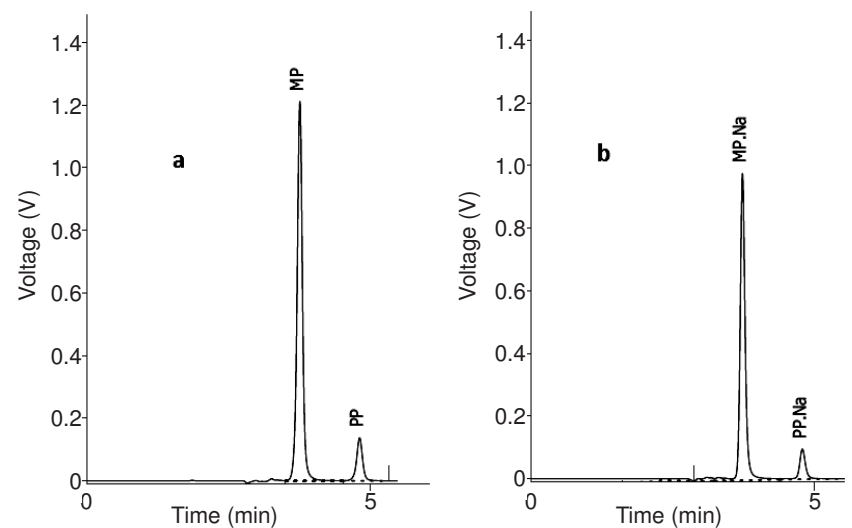

Fig. 2. Chromatogram of standards solutions showing separated peaks of: (a) methyl paraben (MP) and propyl paraben (PP); (b) methyl paraben sodium (MP.Na) and propyl paraben sodium (PP.Na), method (I)
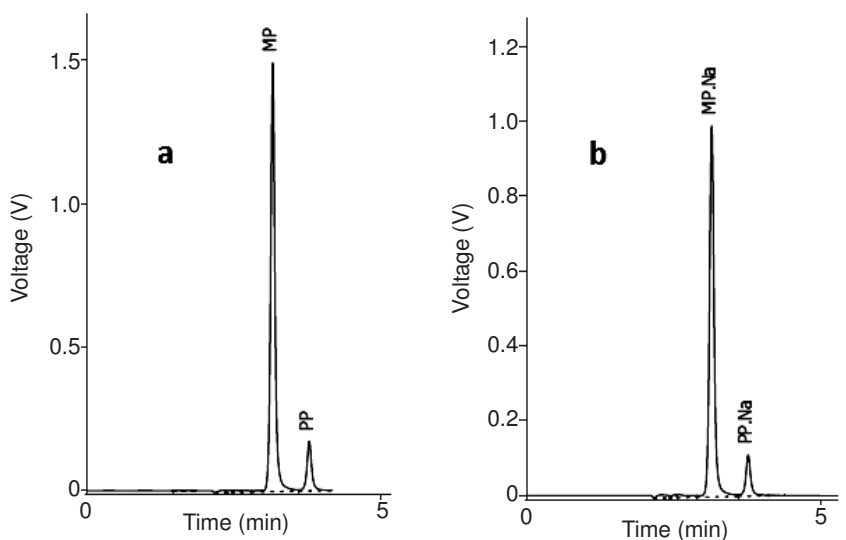

Fig. 3. Chromatogram of standards solutions showing separated peaks of: (a) methyl paraben (MP) and propyl paraben (PP); (b) methyl paraben sodium (MP.Na) and propyl paraben sodium (PP.Na), method (II)

Optimization of the HPLC conditions: The chromatographic conditions were optimized with respect to resolution and time of analysis.

pH effect of mobile phase: Using C18 RP column and mixture of organic solvent (methanol or acetonitrile) and buffers with different mobile phase $\mathrm{pH}$ values in range $(\mathrm{pH}=$ 
2.5-6) was studied. The dependence of the peak area of (methyl paraben and propyl paraben), (methyl paraben sodium and propyl paraben sodium) against $\mathrm{pH}$ values was investigated.

The $\mathrm{pH}$ dependency of the peak area of the esters of $p$ hydroxy benzoic acid (methyl paraben and propyl paraben) and their salts by using (methanol or acetonitrile) and acetate buffer as mobile phase at constant mobile phase component ratios and injected quantity exhibits curves with maximum threshold at the $\mathrm{pH}$ range between 3.5-4.5 for two mentioned conditions.

Increasing in the first part of the curves is due to lower protonation of the oxygen atom of the $\mathrm{C}=\mathrm{O}$ group at higher $\mathrm{pH}$ values. At $\mathrm{pH}$ values higher than the maximums points of the parabens curves, partial process of deprotonation at the hydroxyl group takes place, which is the reason of decreasing of the absorbance at the specific wavelength.

By determining the best $\mathrm{pH}$ range of the preservatives application, we have to take into account the $\mathrm{pH}$ range of their stability. It is known that at $\mathrm{pH}$ above 8 a process of alkaline hydrolysis of parabens takes place, leading to $p$-hydroxy benzoic acid and the corresponding alcohol ${ }^{14}$. Therefore, $\mathrm{pH}$ ranges over 6.5 have to be avoided for parabens. In addition to silica solubility at higher $\mathrm{pH}$ than 8 .

Peaks resolution: The peak resolution of (methyl paraben and propyl paraben) and (methyl paraben sodium and propyl paraben sodium) peaks was identified, by changing the ratios of mobile phase components in both methods at constant mobile phase $\mathrm{pH}=4$. It was concluded that each two peaks was completely separated at the mobile phase ratio, acetate buffer:methanol (14:86) in first method, but in second method the mobile phase ratio was acetate buffer:acetonitrile (17:83). Both mobile phase ratios were obtained at completed separation where peak resolution (Rs) $=1.4$, as seen in (Figs. 4 and 5). Practically, It was found that the best ratio of the mobile phase components where Rs $>1.4$, with obtaining undeformed, symmetrical and fine peaks was presented in Table-1.

\section{Methods validation}

Linearity: System linearity was determined by analysis of five replicates of five standards concentrations of (methyl paraben and propyl paraben), (methyl paraben sodium and propyl paraben sodium) in both methods (I, II), as it is seen in Figs. 6 and 7 (Table-2).

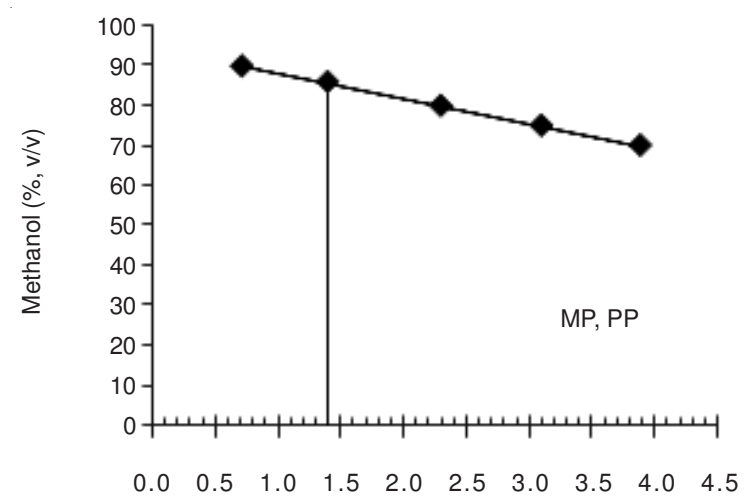

Rs

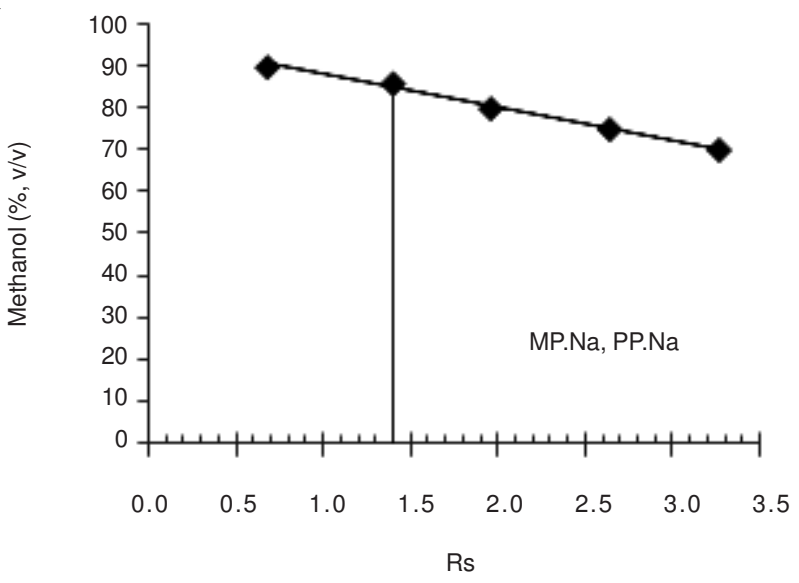

Fig. 4. Peaks resolution Rs for [methyl paraben (MP) and propyl paraben (PP)], [methyl paraben sodium (MP.Na) and propyl paraben sodium (PP.Na)], method (I)
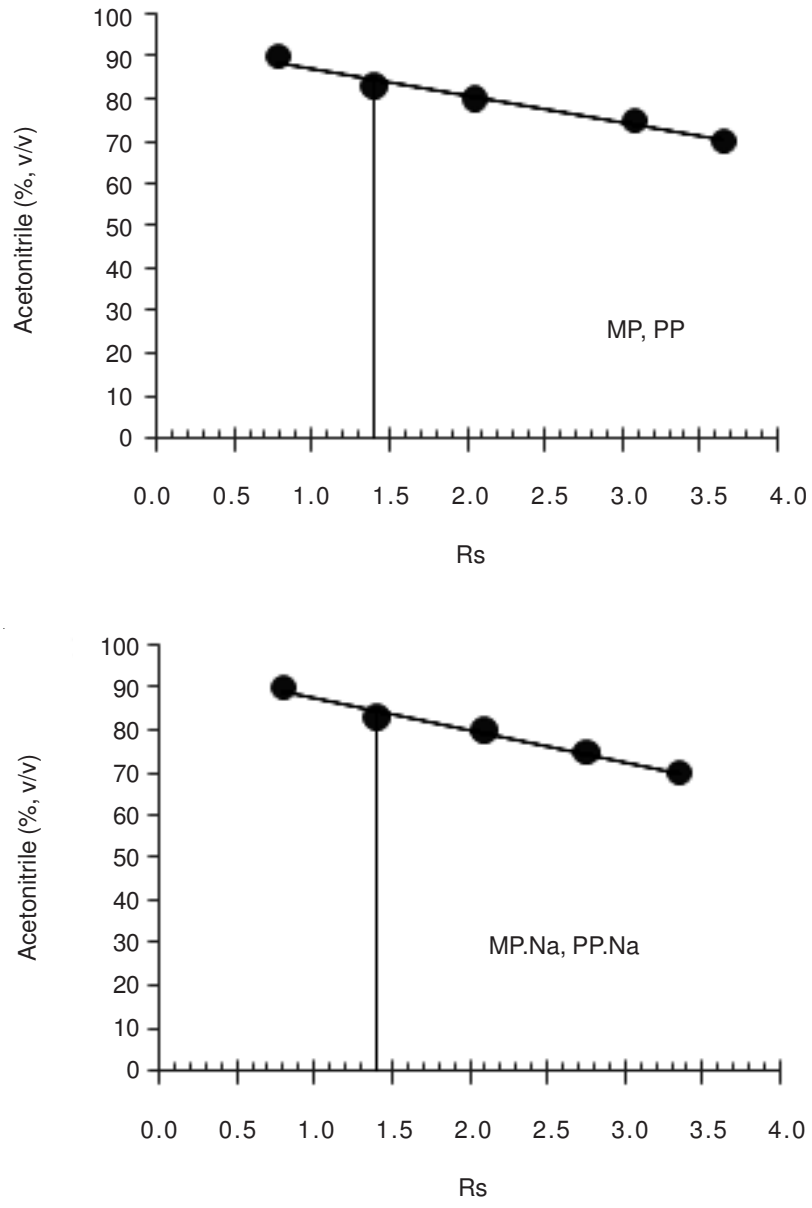

Fig. 5. Peaks resolution Rs for [methyl paraben (MP) and propyl paraben (PP)], (methyl paraben sodium (MP.Na) and propyl paraben sodium (PP.Na)], method (II)

Accuracy/recovery: The accuracy of the method was checked by evaluating the experimental concentration of the solutions prepared for the linearity test versus the nominal concentration. Good recovery of (methyl paraben and propyl paraben), (methyl paraben sodium and propyl paraben sodium) by two methods was observed as shown in Table- 2 . 


\begin{tabular}{|c|c|c|c|c|c|c|c|c|}
\hline \multicolumn{9}{|c|}{$\begin{array}{c}\text { TABLE- } 2 \\
\text { SOME OF THE VALIDATION PARAMETERS FOR PRESERVATIVES ASSAY }\end{array}$} \\
\hline & Component & $\begin{array}{l}\text { Linearity } \\
(\mathrm{mg} / \mathrm{mL})\end{array}$ & $\begin{array}{l}\text { Regression } \\
\text { equation }\end{array}$ & $\begin{array}{l}\text { Correlation } \\
\text { coefficient }\end{array}$ & $\begin{array}{c}\text { Recovery } \\
\text { average } \\
(\%)\end{array}$ & $\begin{array}{l}\frac{\text { Precision }(\% \text { RSD })}{\text { System }} \\
\text { Precision }(n=5)\end{array}$ & $\begin{array}{c}\text { Limit of } \\
\text { quantification } \\
(\mu \mathrm{g} / \mathrm{mL})\end{array}$ & $\begin{array}{r}\text { Limit of } \\
\text { detection } \\
(\mu \mathrm{g} / \mathrm{mL})\end{array}$ \\
\hline \multirow{4}{*}{$\begin{array}{l}\text { First } \\
\text { method }\end{array}$} & Methyl paraben & $0.020-0.20$ & $y=12.12 x+0.056$ & 0.999 & 100.07 & 0.87 & 4.50 & 1.50 \\
\hline & Propyl paraben & $0.004-0.04$ & $y=10.84 x+0.012$ & 0.999 & 100.33 & 0.90 & 1.70 & 0.50 \\
\hline & Methyl paraben sodium & $0.020-0.20$ & $y=11.60 x-0.006$ & 0.999 & 100.29 & 1.32 & 6.50 & 2.20 \\
\hline & Propyl paraben sodium & $0.004-0.04$ & $y=8.013 x+0.002$ & 0.999 & 99.99 & 0.87 & 2.02 & 0.67 \\
\hline \multirow{4}{*}{$\begin{array}{l}\text { Second } \\
\text { method }\end{array}$} & Methyl paraben & $0.010-0.14$ & $y=12.52 x+0.032$ & 0.999 & 100.22 & 0.57 & 1.90 & 0.60 \\
\hline & Propyl paraben & $0.002-0.03$ & $y=10.71 x+0.012$ & 0.999 & 100.09 & 0.84 & 0.56 & 0.18 \\
\hline & Methyl paraben sodium & $0.010-0.14$ & $y=10.01 x+0.031$ & 0.999 & 100.51 & 0.66 & 2.40 & 0.80 \\
\hline & Propyl paraben sodium & $0.002-0.03$ & $y=7.482 x+0.006$ & 0.999 & 100.06 & 0.73 & 0.66 & 0.22 \\
\hline
\end{tabular}
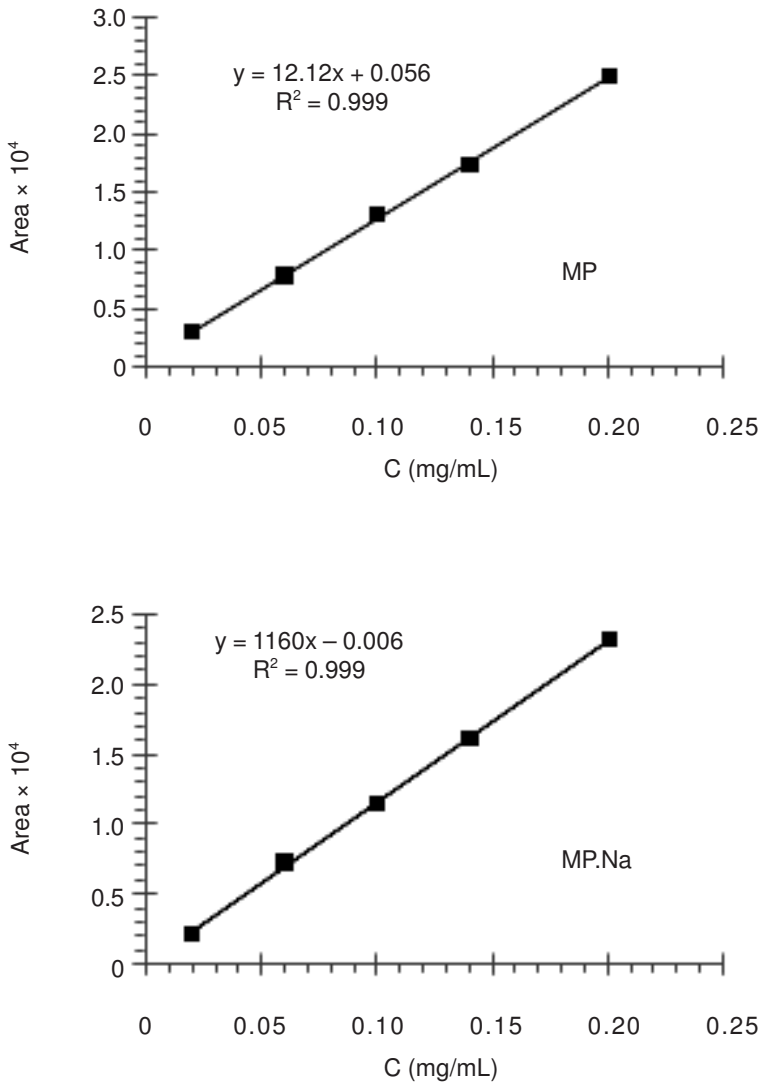
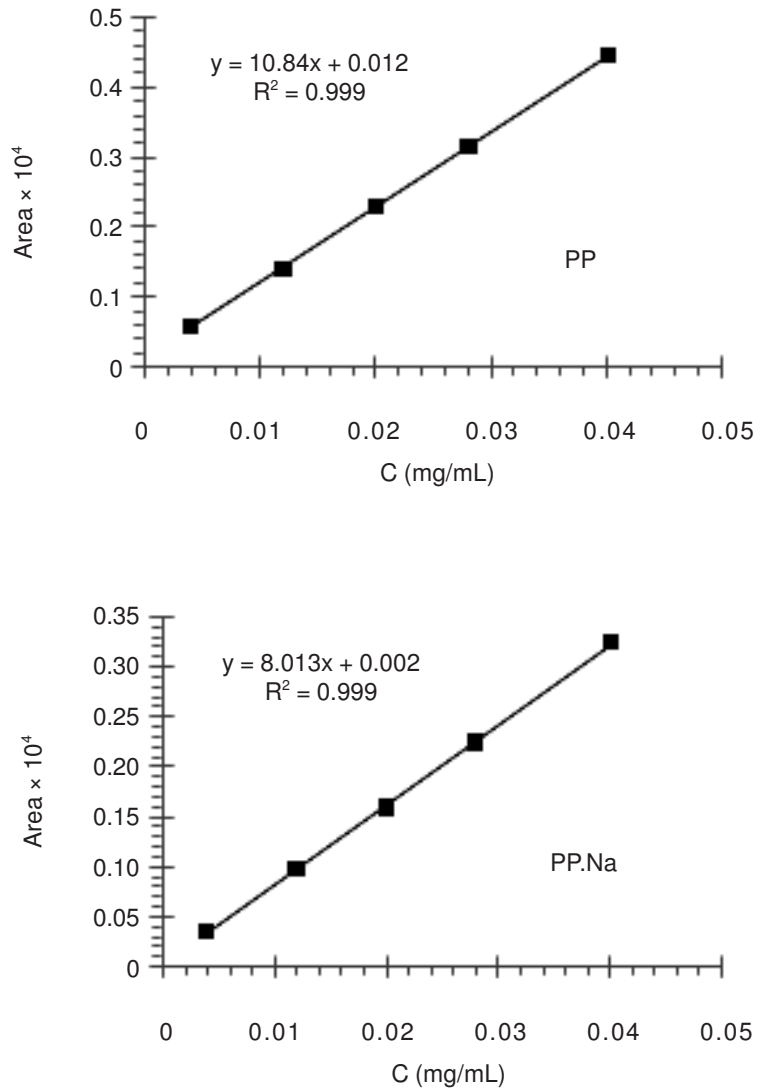

Fig. 6. Linearity graphs of [methyl paraben (MP) and propyl paraben (PP)], [methyl paraben sodium (MP.Na) and propyl paraben sodium (PP.Na)], method (I)

\section{Precision}

System precision: Five replicates $(n=5)$ of a standard mixture solution $(0.1 \mathrm{mg} / \mathrm{mL}$ methyl paraben and $0.02 \mathrm{mg} /$ $\mathrm{mL}$ propyl paraben $),(0.1 \mathrm{mg} / \mathrm{mL}$ methyl paraben sodium and $0.02 \mathrm{mg} / \mathrm{mL}$ propyl paraben sodium) were analyzed to assess system precision. The RSD of peak area response (Table-2) showed the satisfactory repeatability of the system $(<2 \%)$.

Method precision: Five replicates $(n=5)$ of sample solutions were analyzed in the same day to determine method precision. The low RSD $(<2 \%)$ showed the suitability of the method for the determination of (methyl paraben and propyl paraben), (methyl paraben sodium and propyl paraben sodium) in oral and injection formulation, the method precision was summarized in Table- 3 .
Limit of detection (LOD) and limit of quantification (LOQ): The limit of detection and limit of quantification were obtained from the calibration curves. The limit of detection and limit of quantification were calculated based on the standard deviation of the intercept $(\mathrm{SD}=\delta)$ and the slope $(\mathrm{S})$ of the calibration curves using the formulae $3.3 \delta / \mathrm{S}$ and 10 $\delta / \mathrm{S}$ respectively. The limit of detection and limit of quantification concentrations were reported in Table-2.

Specificity: It was determined (methyl paraben and propyl paraben), (methyl paraben sodium and propyl paraben sodium) in both methods in all samples without any interference. Peaks were completely separated with good resolution and specificity. Confirming the specificity of the method; the peaks of (methyl paraben and propyl paraben), (methyl paraben sodium and propyl paraben sodium) in the samples 

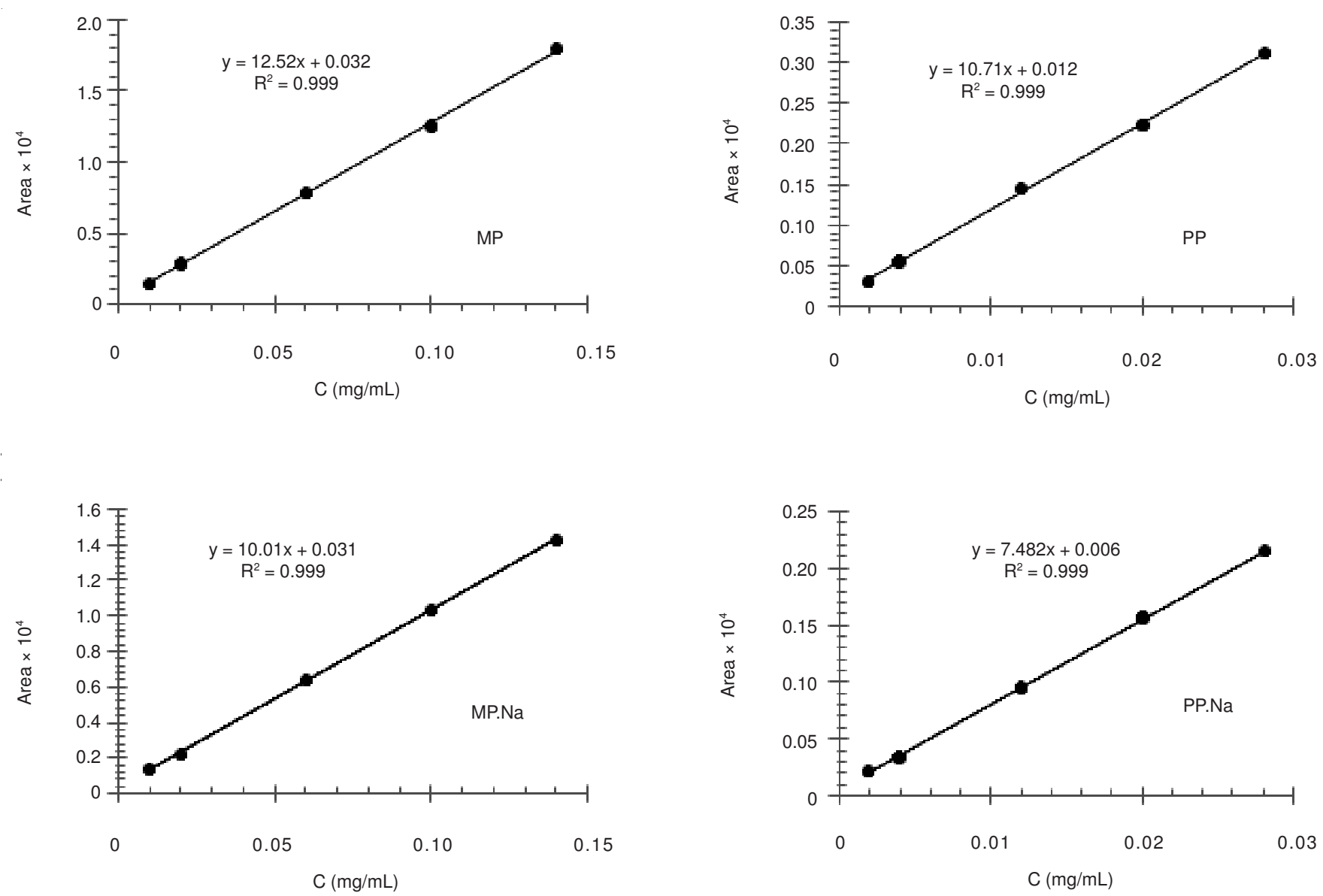

Fig. 7. Linearity graphs of [methyl paraben (MP) and propyl paraben (PP)], [methyl paraben sodium (MP.Na) and propyl paraben sodium (PP.Na)], method (II)

\begin{tabular}{|c|c|c|c|c|c|c|}
\hline \multicolumn{7}{|c|}{$\begin{array}{c}\text { TABLE-3 } \\
\text { METHYL PARABEN, PROPYL PARABEN AND THEIR SALTS CONTENTS IN ORAL AND INJECTION FORMULATIONS PRODUCTS }\end{array}$} \\
\hline \multirow{2}{*}{ Trade name } & \multirow{2}{*}{ Company } & \multirow{2}{*}{ Component } & \multicolumn{2}{|c|}{ Method (I) } & \multicolumn{2}{|c|}{ Method (II) } \\
\hline & & & $\overline{\mathrm{X}}(\mathrm{mg} / \mathrm{mL})_{\mathrm{n}=5}$ & RSD (\%) & $\overline{\mathrm{X}}(\mathrm{mg} / \mathrm{mL})_{\mathrm{n}=5}$ & $\operatorname{RSD}(\%)$ \\
\hline \multirow[t]{2}{*}{ Amrivite-F (Injection) } & \multirow[t]{2}{*}{ Amrit } & Methyl paraben sodium & 1.25 & 0.93 & 1.12 & 0.69 \\
\hline & & Propyl paraben sodium & 0.26 & 1.88 & 0.27 & 1.43 \\
\hline \multirow[t]{2}{*}{ Amrivite (Injection) } & \multirow[t]{2}{*}{ Amrit } & Methyl paraben sodium & 1.34 & 1.45 & 1.07 & 1.02 \\
\hline & & Propyl paraben sodium & 0.25 & 1.82 & 0.26 & 1.80 \\
\hline \multirow[t]{2}{*}{ Dexamrit (Injection) } & \multirow[t]{2}{*}{ Amrit } & Methyl paraben sodium & 1.39 & 1.68 & 1.25 & 0.87 \\
\hline & & Propyl paraben sodium & 0.21 & 1.86 & 0.19 & 1.88 \\
\hline \multirow[t]{2}{*}{ Stigmin (Injection) } & \multirow[t]{2}{*}{ Amrit } & Methyl paraben sodium & 1.33 & 0.73 & 1.06 & 1.42 \\
\hline & & Propyl paraben sodium & 0.16 & 1.76 & 0.22 & 1.95 \\
\hline \multirow[t]{2}{*}{ Ketotiphen (Syrup) } & \multirow[t]{2}{*}{ Amrit } & Methyl paraben & 1.23 & 0.68 & 1.44 & 1.02 \\
\hline & & Propyl paraben & 0.21 & 1.03 & 0.18 & 1.51 \\
\hline \multirow[t]{2}{*}{ Dexamrit (Syrup) } & \multirow[t]{2}{*}{ Amrit } & Methyl paraben & 0.79 & 1.21 & 1.09 & 1.26 \\
\hline & & Propyl paraben & 0.17 & 1.52 & 0.18 & 1.76 \\
\hline \multirow[t]{2}{*}{ Salbutamol (Syrup) } & \multirow[t]{2}{*}{ Amrit } & Methyl paraben & 1.34 & 1.30 & 1.49 & 1.37 \\
\hline & & Propyl paraben & 0.21 & 1.73 & 0.17 & 1.70 \\
\hline \multirow[t]{2}{*}{ Acephyllin (Syrup) } & \multirow[t]{2}{*}{ Amrit } & Methyl paraben & 1.09 & 1.37 & 1.24 & 0.95 \\
\hline & & Propyl paraben & 0.18 & 1.52 & 0.19 & 1.79 \\
\hline \multirow[t]{2}{*}{ Algiscon (Oral suspension) } & \multirow[t]{2}{*}{ Delta } & Methyl paraben & 1.16 & 1.13 & 1.23 & 1.05 \\
\hline & & Propyl paraben & 0.27 & 1.45 & 0.28 & 1.34 \\
\hline \multirow[t]{2}{*}{ Pectomex (Syrup) } & \multirow[t]{2}{*}{ Razi } & Methyl paraben & 1.29 & 1.01 & 1.42 & 0.95 \\
\hline & & Propyl paraben & 0.37 & 1.16 & 0.43 & 1.22 \\
\hline \multirow[t]{2}{*}{ Barkacine (Drops) } & \multirow[t]{2}{*}{ Barakat } & Methyl paraben & 1.18 & 0.99 & 1.26 & 1.86 \\
\hline & & Propyl paraben & 0.52 & 1.41 & 0.56 & 1.89 \\
\hline
\end{tabular}


were identified by comparing the retention time with that of the standards.

Application of the assay: The applicability of two HPLCUV methods was investigated for pharmaceutical preparations (syrup, ampoule). In all the preparations, the amount of (methyl paraben and propyl paraben), (methyl paraben sodium and propyl paraben sodium) was obtained by direct measurement using the standard calibration curve. The total analysis time was less than 6 min with good resolution, good peak shapes and minimal tailing. Four pharmaceutical formulations containing (methyl paraben sodium and propyl paraben sodium) and seven pharmaceutical formulations containing (methyl paraben and propyl paraben) were analyzed. The results obtained by the proposed methods are in satisfactory agreement. The analytical results are summarized in Table-3.

\section{Conclusion}

Proposed HPLC methods are direct, specific, rapid and precise for simultaneous determination of (methyl paraben and propyl paraben), (methyl paraben sodium and propyl paraben sodium) in oral and injection formulations. It was found that the second method is more sensitive and faster than the first one.

The described two methods are suitable for routine analysis and quality control of oral and injection containing these two preservative ingredients, either alone or in combination.

It was found that there is very small difference of mobile phase ratio, necessary to separate methyl paraben and propyl paraben or their salts in both methods.

In samples contain (methyl paraben and propyl paraben) or their sodium salts, the added amounts of those preservative were in allowable safety limits and did not exceed the authorized limits.

\section{ACKNOWLEDGEMENTS}

This work was financially and technically supported by the Ministry of High Education through University of Aleppo, Faculty of Science, Department of Chemistry, Aleppo, Syria.

\section{REFERENCES}

1. H. Yamazaki, T. Yoneda and T. Yamaguchi, Japan. J. Food Chem., 5, 130 (1998).

2. H. Lord and J. Pawliszyn, J. Chromatogr. A, 902, 17 (2000).

3. S.H. Kang and H. Kim, J. Pharm. Biomed. Anal., 15, 1359 (1997).

4. The Japanese Standards of Cosmetic Ingredients-with Commentary, The Society of Japanese Pharmacopoeia, Yakuginippousha, Tokyo, edn. 2 (1984).

5. J. Aluoch-Orwa, I. Quintens, E. Roets and J. Hoogmartens, Eur. J. Pharm. Sci., 3, 301 (1995).

6. S. Vidovic, B. Stojanovic, J. Veljkovic, L. Prazic-Arsic, G. Roglic and D. Manojlovic, J. Chromatogr. A, 1202, 155 (2008).

7. M. Pedrouzo, F. Borrull, R.M. Marcé and E. Pocurull, J. Chromatogr. A, 1216, 6994 (2009).

8. M.R. Lee, C.Y. Lin, Z.G. Li and T.F. Tsai, J. Chromatogr. A, 1120, 244 (2006).

9. Y.Q. Chen and Y.N. Ni, Chin. Chem. Lett., 20, 615 (2009).

10. Y. Wang, Y. Cao, C. Fang and Q. Gong, Anal. Chim. Acta, 673, 145 (2010).

11. J.F. García-Jiménez, M.C. Valencia and L.F. Capitán-Vallvey, Anal. Chim. Acta, 594, 226 (2007).

12. T.J. Yang, F.J. Tsai, C.Y. Chen, T.C.-C. Yang and M.R. Lee, Anal. Chim. Acta, 668, 188 (2010).

13. M. Blanco, M. Alcala and M. Bautista, Eur. J. Pharm. Sci., 33, 409 (2008).

14. I. Polonen, Ph.D. Thesis, University of Helzinki, Finland (2000). 